\title{
ADULTS’ DIFFICULTIES IN THE PROCESS OF LEARNING OUTCOMES PORTFOLIO DEVELOPMENT: CONSULTANTS’ PERCEPTIONS
}

\author{
Nijolè Burkšaitienè \\ Mykolas Romeris University, Institute of Humanities \\ Department of Applied Languages \\ Ateities 20, LT-08303 Vilnius, Lithuania \\ Tel. (+370 5) 2714613 \\ E-mail: n.burksaitiene@mruni.eu
}

Received 2 August, 2013; accepted 21 October, 2013

doi:10.13165/SMS-13-5-4-12

\begin{abstract}
Recently, a number of higher education institutions in Lithuania have started introducing validation of non-formal and informal learning, which requires adopting necessary institutional legal acts, establishing the procedure which ensures that assessment meets quality requirements, training administrative and teaching staff, and creating mechanisms of guidance and support to adults. Until now, little known research has focused on institutional guidance and support provided to adults and the perceptions of institutional participants in the process. The purpose of this study is to examine consultants' perceptions of difficulties that adults encounter in the process of learning outcomes portfolio development before the assessment procedure of their non-formal and informal learning in four higher education institutions. The findings revealed that adults faced time constraints, difficulties related to identification and documentation of their learning outcomes, as well as difficulties due to the novelty of the procedure and adults' personal characteristics. It is recommended that this study be extended to the investigation of difficulties that consultants encountered in the process of providing guidance and support to adults.
\end{abstract}

Socialiniu mokslu studijos / Societal Studies

(C) Mykolo Romerio universitetas, 2013

(C) Mykolas Romeris University, 2013
ISSN 2029-2236 (print), ISSN 2029-2244 (online) http://www.mruni.eu/lt/mokslo_darbai/SMS/ http://www.mruni.eu/en/mokslo_darbai/SMS/ 
Keywords: adults' difficulties, learning outcomes portfolio development, institutional guidance and support to adults, claim for credit, higher education.

\section{Introduction}

Relevance of the study and research problem. Validation of non-formal and informal learning has become a reality in European higher education, however, the degree of involvement in the process differs across countries considerably. The existing differences include the level of strategy formation and legal regulation, purposes of validation, participation of stakeholders, sources of financing, and terminology used to define the process $^{1}$. In Lithuania, validation of non-formal and informal learning has been on policy agenda since $1998^{2}$, however, legal acts regulating the process in higher education were adopted only in 2009 and $2010^{3}$, thus, validation at this level of education is still at a stage of development. Even though legislation was adopted only a few years ago, some universities and colleges have been working in this field on the project-funded basis for about a decade and have already gained some experience in the area. At present, for the majority of higher education institutions in Lithuania validation still poses a major challenge as they either do not have any experience in assessing learning outcomes gained in diverse learning environments at all or are at the stage of introducing validation. This is a challenge to institutions where traditionally the most valuable learning outcomes have been those acquired within the academia and where academic staff has never assessed learning outcomes gained outside it $^{4}$.

1 The European Higher Education Area in 2012. Bologna Process Implementation Report. Brussels: Education, Audiovisual and Culture Executive Agency, 2012; Bjornavold, J. Validation of Non-formal and Informal Learning in Europe: Key Developments and Challenges. Aukštojo mokslo kokybe / The Quality of Higher Education. 2009, 6: 36-71; Burkšaitienè, N.; Šliogeriené, J. Neformaliojo ir savaiminio mokymosi pasiekimu vertinimas ir pripažinimas universitete. Vilnius: MRU, 2010.

2 Republic of Lithuania. Law on Non-formal Adult Education (No VIII-822) [interactive]. 1998 [accessed on 10-08-2013]. <http://www3.lrs.lt/pls/inter2/dokpaieska.showdoc_l?p_ id $=370996>$.

3 Republic of Lithuania. Law on Higher Education and Research (No XI-242), 30 April 2009 [interactive]. 2009 [accessed on 08-08-2013]. <http://www3.lrs.lt/pls/inter3/dokpaieska. showdoc_l?p_id=366717>; LR švietimo ir mokslo ministro įsakymas (Nr. V-2319) Dél neformaliojo suaugusiuju švietimo sistemoje igytu kompetencijų vertinimo ir pripažinimo aukštosiose mokyklose rekomendaciju patvirtinimo [interactive]. 2010 [accessed on 08-08-2013]. $<$ http://tar.tic.lt/Default.aspx?id=2\&item=results\&aktoid=7E500082-A72F-47D3-82BF-A0B18D56FBE8>.

4 Burkšaitienè, N.; Šliogerienė J., supra note 1; Finn, J. Validation of Non-formal Adult Education Courses: A New Validation Function for Higher Education Institutions in Europe. In Validation and Recognition of Experiential Learning. Teresevičiené, M., et al. (Eds.). Kaunas: VDU, 2007. 
Recently, a number of universities and colleges in Lithuania have started introducing validation of non-formal and informal learning. To implement assessment and recognition of this type of learning successfully, they have to adopt necessary institutional legal acts, establish the procedure which ensures that assessment meets quality requirements, train administrative and teaching staff, and create mechanisms of guidance and support to adults. Institutional support mechanisms accessible to adults throughout the entire process of validation play an important role in the process, in particular guidance and support provided to adults before the assessment procedure. This is predetermined by specificity of assessment of non-formal and informal learning, i.e. adults have to take it before they enter an institution, not all learning outcomes can be easily defined (e.g. learning outcomes gained at one's workplace) and, therefore, they have to be discussed and agreed upon between the adult and the institution before the assessment procedure ${ }^{5}$. In addition, identifying one's learning outcomes, matching them against the learning outcomes required in a particular study programme and documenting such a match have been reported in research as posing a major challenge to adults ${ }^{6}$.

Until now, little research has been available on institutional guidance and support to adults and the experiences of institutional participants in the process. In this article, we address institutional guidance and support provided to adults by consultants before the assessment procedure. The aim of the present research is to analyse perceptions of consultants towards difficulties that were encountered by adults in the process of preparation for assessment. The research objectives include elaborating on the current situation of validation of non-formal and informal learning in European Higher Education Area and Lithuania, describing the context of the present study and examining perceptions of institutional participants in the process. To carry out the research, a qualitative methodology of content analysis was used.

The aim of this article is to report the results of the study into consultants' perceptions of difficulties that adults encountered before the assessment procedure of their non-formal and informal learning outcomes in four higher education institutions.

5 Joosten-ten Brinke, D.; Sluijsmans, D.M.A.; Jochems, W.M.G. Quality of Assessment of Prior Learning (APL) in University Programmes: Perceptions of Candidates, Tutors and Assessors. Studies in Continuing Education. 2009, 31 (1): 61-76; Boud, D. cited in Costley, C.; Armsby, P. Work-based Learning Assessed as a Field or a Mode of Study. Assessment \&Evaluation in Higher Education. 2007, 32 (1): 25.

6 Rydel, S.T. Building on the Past, Moving Toward the Future: Prior Learning Assessment in a Changing Institution at Metropolitan State University. In Portfolio Development and the Assessment of Prior Learning: Perspectives, Models and Practices. Michelson, E.; Mandell, A. (Eds.). Sterling: Stylus Publishing, 2004, p. 180-193; Peters, H.; Pokorny, H.; Johnson, L. Cracking the Code: The Assessment of Prior Experiential Learning at London Metropolitan University. In Portfolio Development and the Assessment of Prior Learning: Perspectives, Models and Practices. Michelson, E.; Mandell, A. (Eds.). Sterling: Stylus Publishing, 2004, p. 160-179; Burkšaitienè, N.; Teresevičienė, M.; Kaminskienè, L. Portfolio Use for Documentation of Personal and Professional Growth Gained outside Academia. Baltic Journal of Management. 2011, 6 (2): 245-262. 


\section{Validation of Non-formal and Informal Learning in Euro- pean Higher Education Area}

Validation of non-formal and informal learning has been on the European lifelong learning policy agenda for over a decade and its implementation is still under development. In 1999, Declaration "European Higher Education Area" was signed in Bologna by 29 ministers responsible for higher education in Europe, which marked the beginning of Bologna process. A year later, the European Commission issued "A Memorandum of Lifelong Learning" which stressed the importance of establishing procedures of validation of non-formal and informal learning in higher education for lifelong learning in Europe. Since then, validation of non-formal and informal learning has become a policy issue on the agenda of member countries of Bologna process. What has been achieved since then? According to the 2012 report on Bologna process implementation ${ }^{8}$, validation of non-formal and informal learning within European Higher Education Area has become a reality, however, the degree of involvement in the process differs across countries considerably. The existing differences include the level of strategy formation and legal regulation (national level, institutional level), purposes of validation (access to higher education, credit award and/or exemption from a course or part of a programme, qualification award), participation of stakeholders (governmental institutions, employers, voluntary organisations, youth organisations, etc.), sources of financing (self-financing, state and employer financing, combination of different financing sources, etc.), and terminology used to define the process ${ }^{9}$. According to the report, higher education systems of Bologna process polarize into two extremely distinct groups: the first group comprises 13 countries (France, Great Britain, Germany, Norway, Belgium and other countries) that by 2012 have well-established systems of recognition of non-formal and informal learning, i.e. have introduced national laws to validate non-formal and informal learning and where recognition of such learning is implemented in accordance with the established procedure for both access to higher education and progression in studies (i.e. allocation of credits and/or the exemption from part of the programme). The opposite group includes 12 higher education systems that have not started their activities in the area yet (Greece, Cyprus, Serbia, Romania, Bulgaria and other countries). In other Bologna process countries there exist nationally established procedures, guidelines or policies either for access to higher education or for progression in studies, but the procedures are not widely applied or there are no national guidelines or policy for validation, but procedures for recognition of such type of learning have been established in some higher education institutions or study programmes. The report concludes that in 29 higher education systems in the European Higher Education Area from the total of 47 higher education systems (for which data was available) non-formal and informal learning can be taken into account towards the completion of studies, and a slightly higher number

8 The European Higher Education Area in 2012, supra note 1.

9 Ibid.; Bjornavold, J., supra note 1; Burkšaitienè, N.; Šliogerienè, J., supra note 1. 
of countries use the recognition of non-formal and informal learning for progression in studies, however, only 13 higher education systems can offer both possibilities. It is also reported that in higher education systems in Bologna process countries regulations often specify the limits to the number of credits that can be acquired via validation procedure and that recognition of non-formal and informal learning rarely leads to an award of a higher education qualification ${ }^{10}$.

\section{Validation of Non-formal and Informal Learning in Higher Education in Lithuania}

According to the report ${ }^{11}$, Lithuania alongside with 10 countries (Poland, Latvia, Austria, Croatia and other countries) belongs to the group of higher education systems where the process of recognition of non-formal and informal learning can be used either for access to higher education institutions only or for progression in higher education studies only or for both purposes. In Lithuania, validation of non-formal and informal learning has been on policy agenda since 1998 when the Law on Adults' Non-formal Education was passed ${ }^{12}$, however, legal acts regulating the process at the level of higher education were adopted only in 2009 and $2010^{13}$. Even though legislation was adopted only a few years ago, some universities and colleges have been working in this field on the projectfunded basis for about a decade and have already gained some experience in the area ${ }^{14}$. At present, for the majority of higher education institutions validation still poses a major challenge as they either do not have any experience in assessing learning outcomes gained in diverse learning environments at all or are at the stage of introducing validation. This is a complex task to institutions where traditionally the most valuable learning outcomes have been those acquired within the academia and where academic staff has never assessed learning outcomes gained outside $\mathrm{it}^{15}$. Assessment of non-formal and informal learning is specific as it involves assessment of a complex combination of knowledge, skills and competences before adults enter an institution, which adds to the complexity of the task. Besides, not all learning outcomes can be easily defined (e.g. learning outcomes gained at one's workplace) and, therefore, they have to be discussed and agreed upon between the adult and the institution ${ }^{16}$ before assessment. To establish the procedure of recognition of non-formal and informal learning, institutions have to adopt necessary institutional legal acts, introduce assessment procedure, distribute responsibilities, train administrative and

10 The European Higher Education Area in 2012, supra note 1, p. 143-144.

11 Ibid.

12 Republic of Lithuania. Law on Non-formal Adult Education, supra note 2.

13 Republic of Lithuania Law on Higher Education and Research, supra note 3; LR švietimo ir mokslo ministro ịsakymas Nr. V-2319 Dèl neformaliojo suaugusiuju švietimo sistemoje igytu kompetenciju vertinimo ir pripažinimo aukštosiose mokyklose rekomendacijų, supra note 3.

14 Burkšaitienė, N.; Šliogerienè, J., supra note 1; Burkšaitienė, N.; Teresevičienė, M.; Kaminskienè, L., supra note 6.

15 Finn, J., supra note, 4.

16 Boud, D., cited in Costley, C.; Armsby, P., supra note 5. 
teaching staff, as well as create mechanisms of guidance and support to adults, the major challenge being to ensure that assessment of learning outcomes gained through diverse learning environments meets quality requirements ${ }^{17}$.

According to the recommendations passed by the Minister of Education and Science of the Republic of Lithuania $(2010)^{18}$, the procedure of assessment and recognition of learning outcomes (in recommendations the term learning outcomes is defined as competences) gained through diverse learning environments consists of four stages that (in respect to the processes involved) correspond to the four stages (identification, documentation, assessment and certification) set out in the Council Recommendation (2012) on the validation of non-formal and informal learning ${ }^{19}$ :

1. Information. This is a stage during which adults are informed about validation of non-formal and informal learning at the institution, including assessment principles, procedure, possible outcomes and future prospects, and make their decision to participate in the procedure.

At this stage, institutions must have learning outcomes-based descriptions of study programmes so that there is no ambiguity as to the learning outcomes that traditional students are required to gain after they finish a course (a module), which becomes important guidelines that adults have to follow. Institutional support is provided to adults by administrative staff by answering questions and helping to decide which study programme best suits the adult's needs ${ }^{20}$.

2. Consultation. The purpose of this stage is to provide guidance and support to adults to identify and document their learning outcomes. Adults have to analyse their learning experience, identify competences and document them in a learning outcomes portfolio (portfolio of competences). The most essential requirement is to document learning outcomes so that the evidence of their match with the learning outcomes required in the study programme the adult intends to claim credit from is provided and that documented learning outcomes are of the required academic level allowing to award credit ${ }^{21}$.

The importance of this stage cannot be underestimated as it largely predetermines success of the assessment stage which follows, therefore, it is important to share the responsibility between the institution and the adult. Institution is responsible for providing support to adults by guiding them on establishing a match of their learning outcomes with the learning outcomes outlined in the study programme, on issues of portfolio development and relevance of the evidence, on additional assignment and its

17 Joosten-ten Brinke, D.; Sluijsmans, D.M.A.; Jochems, W.M.G., supra note 5; Burkšaitienė, N.; Šliogerienè, J., supra note 1.

18 LR švietimo ir mokslo ministro įsakymas Nr. V-2319 Dèl neformaliojo suaugusiųju švietimo sistemoje igytų kompetenciju vertinimo ir pripažinimo aukštosiose mokyklose rekomendacijų, supra note 3.

19 Council Recommendation of 20 December 2012 on the Validation of Non-formal and Informal Learning (2012/C398/01) [interactive]. 2012 [accessed on 14-08-2013]. <http://eur-lex.europa.eu/LexUriServ/LexUriServ.do?uri=OJ:C:2012:398:0001:0005:EN:PDF>.

20 Burkšaitienė, N.; Šliogerienè, J., supra note 1; Joosten-ten Brinke, D.; Sluijsmans, D.M.A.; Jochems, W.M.G., supra note 5.

21 Ibid.; Peters, H.; Pokorny, H.; Johnson, L., supra note 6. 
assessment, by consulting on how to prepare for assessment interviews, etc. It is reported in the research that portfolio development courses and/or learning formats comprising portfolio development courses, consultations (on-line, off-line, group, individual, etc.) and regular feedback on adults' progress in developing their portfolio are a valuable form of institutional support ${ }^{22}$. On the other hand, the major responsibility of the adult is to analyse one's learning experience, identify and document learning outcomes so that there is enough proof for a claim of credits.

3. Assessment. Adults' learning outcomes are assessed to establish whether the presented evidence/proof matches the learning outcomes described in a chosen study programme, whether their level satisfies academic requirements and to what extent, i.e. whether award of credit and/or exemption from a course or part of a study programme is possible.

At this stage, institutions must have trained assessors to be able to assess documented learning outcomes. As learning outcomes comprise a combination of knowledge, skills and competences that have to be assessed, a variety of assessment methods, including tests/ examinations, conversational methods, declarative methods, observation, simulations, presentations, etc., has to be used. It is important to ensure that assessment is carried out in line with the established edumetric quality requirements so that quality is assured ${ }^{23}$.

4. Certification. At this stage, assessors or assessing commission make a decision on certification of the assessment results. If it is established that evidence/proof of the adult's learning outcomes meets the required standards, credits are awarded and/or the adult can be exempt from a course (module) or part of the study programme. Also, a formal certificate can be issued if the adult needs it for employment or other purposes.

Institutional support is provided to adults by discussing options on available forms and modes of study to find the one which best suits the adult's needs and career perspectives. If the adult's claim of credit award was rejected, institutional support is important as he or he should be guided on further action, i.e. what can be done and how it has to be done so that to succeed in the future.

\section{Method}

Participants. The present study involved 12 consultants from four higher education institutions (Utena University of Applied Studies, Vilniaus kolegija / University of Applied Sciences, Zemaitija College, and International School of Law and Business) that were introducing validation of non-formal and informal learning and preparing to assess learning outcomes of the first adults who applied to participate in the procedure. The consultants were trained to provide guidance and support to adults on issues related to the

22 Burkšaitienè, N.; Teresevičienė, M.; Kaminskienè, L., supra note 5; Peters, H.; Pokorny, H.; Johnson, L., supra note 6; Burkšaitienè, N.; Šliogerienė, J., supra note 1.

23 Baartman, L.K.J. 'Assessing the Assessment': Development and Use of Quality Criteria for Competence Assessment Programmes. Doctoral Dissertation [interactive]. 2008 [accessed on 12-082013]. <http://igitur-archive.library.uu.nl/dissertations/2008-0423-200627/baartman.pdf>; Joosten-ten Brinke, D.; Sluijsmans, D.M.A.; Jochems, W.M.G., supra note 5. 
process of assessment and recognition of non-formal and informal learning in a definite field of study. Each consultant had to provide guidance and support to a mini group of adults (the number of adults per group ranging from two to six) according to the chosen field of study; none of the consultants had any previous experience in the field.

Guidance and support was provided to 37 volunteer adults who met the minimum education and work experience requirements for the procedure and made a claim for credit from study programmes of different fields of study, including marketing, business, communication, economics, nursing, pedagogics, medicine and health care, accounting, tourism and recreation, and general engineering; none of the adults had participated in the procedure of validation before.

Procedure. All adults received a copy of a manual on how to compile a portfolio of non-formal and informal learning outcomes for credit claim from a particular course (module). The manual included information on different types of learning (formal, informal and non-formal), the description of the course (module) they had chosen which included the required learning outcomes, guidelines on how to identify one's learning outcomes, write a reflection page and extended CV for the assessment procedure.

To guide and support the adults before the assessment procedure, a scheme of consultations has been designed under which individual and group consultations both on-line and off-line (20 hours) were provided, and adults were given four weeks to develop the first version of their portfolio followed by additional four weeks to finalize it.

To analyse consultants' perceptions on difficulties encountered by the adults they supported, the consultants were asked to answer an open-ended question: "What difficulties did the adults encounter in the process of developing their learning outcomes portfolio?" To examine consultants' responses, a qualitative methodology was used. Content analysis revealed repeated themes (categories) that were further analysed and generalised into sub-themes (sub-categories) that were supplemented with samples of evidence.

\section{Results}

Content analysis of consultants' responses to the question "What difficulties did adults encounter in the process of developing their learning outcomes portfolio?" revealed 5 categories of difficulties, including time constraints, difficulties related to identification and documentation of adults' learning outcomes, novelty of the procedure, and personal characteristics (Table 1). 
Table 1. Difficulties encountered by the adults in the process of portfolio development

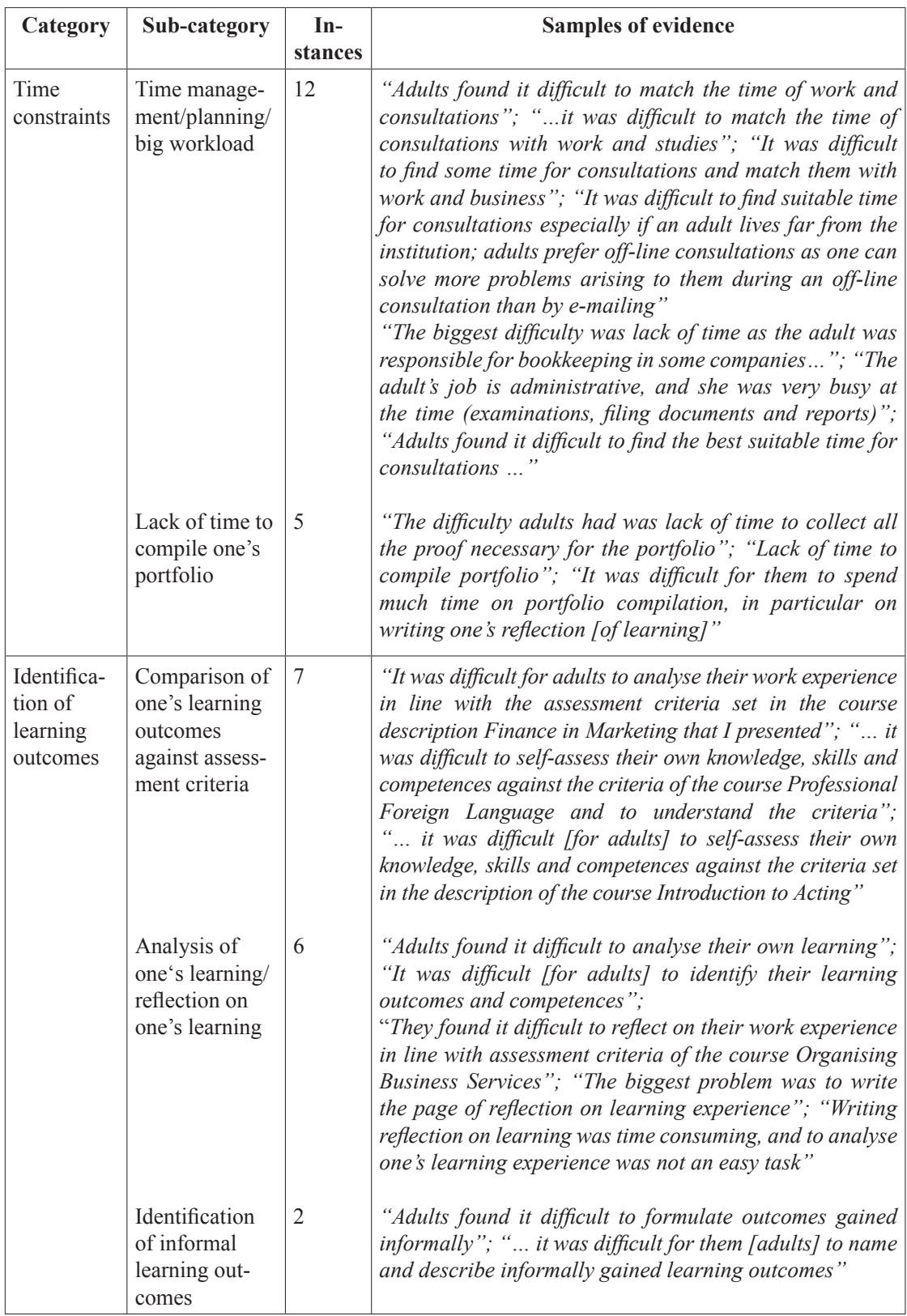




\begin{tabular}{|c|c|c|c|}
\hline $\begin{array}{l}\text { Documen- } \\
\text { tation of } \\
\text { learning } \\
\text { outcomes }\end{array}$ & $\begin{array}{l}\text { Describing } \\
\text { learning } \\
\text { outcomes in a } \\
\text { portfolio }\end{array}$ & 12 & $\begin{array}{l}\text { "It was difficult to collect the necessary proof to be } \\
\text { included in the portfolio"; "Adults had no or little } \\
\text { experience in formalising their competences on the basis } \\
\text { of proof"; "To collect and then select the most suitable } \\
\text { proof of competences was the most difficult task"; "The } \\
\text { major difficulty was to select relevant evidence"; "As } \\
\text { she is very active and initiative in her professional field } \\
\text { (participates in projects, is an expert), she had collected } \\
\text { a huge amount of evidence, thus it was difficult to select } \\
\text { that which was relevant to prove her competences in } \\
\text { andragogy"; "Adults found it difficult to select evidence } \\
\text { which best proved their learning outcomes according } \\
\text { to the course of Practical Training"; "It was very } \\
\text { difficult to prove informal learning outcomes"; "It was } \\
\text { difficult to present proof of competences gained through } \\
\text { participation in voluntary activities" } \\
\text { "It was difficult for adults to describe their learning } \\
\text { outcomes gained in various learning environments, } \\
\text { difficult to describe one's major achievements"; "Adults } \\
\text { were unable to present description of knowledge and } \\
\text { skills gained non-formally and informally" }\end{array}$ \\
\hline $\begin{array}{l}\text { Novelty } \\
\text { of the } \\
\text { procedure }\end{array}$ & $\begin{array}{l}\text { Difficulty in } \\
\text { understanding } \\
\text { the procedure/ } \\
\text { portfolio }\end{array}$ & 3 & $\begin{array}{l}\text { "Adults had a lot of questions about the procedure and the } \\
\text { portfolio"; "Portfolio development was a new experience, } \\
\text { therefore, adults had a lot of questions about it"; "Adults } \\
\text { had a lot of questions on the structure of the portfolio"; } \\
\text { "They [Adults] didn't understand what reflection was and } \\
\text { why it was necessary" } \\
\text { "As this is a new procedure, adults doubted its benefits"; } \\
\text { "Adults expressed doubts if the benefits of the procedure } \\
\text { would be real" }\end{array}$ \\
\hline $\begin{array}{l}\text { Personal } \\
\text { character- } \\
\text { istics }\end{array}$ & $\begin{array}{l}\text { Lack of } \\
\text { self-confidence } \\
\text { Lack of } \\
\text { determination }\end{array}$ & 4 & $\begin{array}{l}\text { "They [Adults] doubted if they were capable enough to } \\
\text { develop their portfolio" } \\
\text { "Adults were not sure if they really wanted to participate } \\
\text { in the procedure"; "When a difficulty in developing } \\
\text { a portfolio arose adults started hesitating whether to } \\
\text { participate in the procedure"; "Two adults refused to } \\
\text { participate in the procedure after they learnt about the } \\
\text { requirement to develop one's portfolio" }\end{array}$ \\
\hline
\end{tabular}

Category 1: time constraints. All consultants highlighted time constraints as the difficulty which the adults encountered in the process of developing their learning outcomes portfolio, including time management and/or planning, big workload and lack of time to compile their learning outcomes portfolio. 
The consultants mentioned that at the time of portfolio development all adults had a job, some adults' job was their own business, some had more than one job and some of them studied, which made it difficult to set the most suitable time for consultations in line with their working hours, business or studies: "Adults found it difficult to match the time of work and consultations", “... it was difficult to match the time of consultations with work and studies" or "The biggest difficulty was lack of time as the adult was responsible for bookkeeping in some companies...", and "Her job is administrative, and she was very busy at the time (examinations, filing documents and reports)".

This is related to another difficulty which was mentioned by as many as five consultants, i.e. the adults found it difficult to allocate enough time to compile their learning outcomes portfolio: "The difficulty adults had was lack of time to collect all the proof necessary for the portfolio" and "It was difficult for them [adults] to spend much time on portfolio compilation, in particular on writing one's reflection [of learning]".

To ensure access to guidance and support, the scheme of both on-line and offline consultations was designed, which proved to be reasonable as only one consultant reported that it was difficult to find suitable time for off-line consultations for an adult who lived far from the institution, because the adult preferred off-line consultations and considered them to be more effective "... as one can solve more problems arising during an off-line consultation than by e-mailing" (Table 1).

Category 2: identification of learning outcomes. The consultants mentioned three main problem areas in identifying learning outcomes that the adults faced, namely analysing one's learning and reflecting on it, comparing non-formal and informal learning outcomes against assessment criteria described in the course programme and identifying informal learning outcomes. Six consultants highlighted adults' difficulty to analyse and reflect on their learning experience: "It was difficult [for adults] to identify learning outcomes and competences", "The biggest problem was to write the page of reflection on learning experience" and "Writing reflection on learning was time consuming, and to analyse one's learning experience was not an easy task". As many as seven consultants stressed that the adults found the task of comparing their learning outcomes against assessment criteria of the chosen course challenging: "It was difficult for adults to analyse their work experience in line with the assessment criteria set in the course description Finance in Marketing that I presented" and "... it was difficult [for adults] to self-assess their own knowledge, skills and competences against the criteria of the course Professional Foreign Language and to understand the criteria". On the other hand, the difficulty of identifying informally gained learning outcomes was less often mentioned, just two consultants said: "Adults found it difficult to formulate outcomes gained informally" and "... it was difficult for them [adults] to name and describe informally gained learning outcomes" (Table 1). This may be due to the fact that the adults considered their work-based learning and non-formal learning outcomes to be easier comparable against the requirements of study programmes than their informal learning outcomes.

Category 3: Documentation of learning outcomes. This difficulty includes two aspects: collecting and/or selecting relevant proof and describing identified learning outcomes in a portfolio. All consultants mentioned that collecting and, in particular, selecting evidence which is relevant to prove the match of non-formal and informal learning outcomes with the learning outcomes presented in the course description posed a major challenge to 
the adults: "It was difficult to collect the necessary proof to be included in the portfolio", "Adults had no or little experience in formalising their competences on the basis of proof", "To collect and then select the most suitable proof of competences was the most difficult task" or "The major difficulty was to select relevant evidence", "As she is very active and initiative in her professional field (participates in projects, is an expert), she had collected a huge amount of evidence, thus it was difficult to select that which was relevant to prove her competences in andragogy", and "It was very difficult to prove informal learning outcomes". This may be due to the fact that some of the adults were professionally active and had a long record of learning experience; therefore, they had collected big amounts of evidence of participation in various learning activities, but none of them had any experience of proving their learning outcomes as required for this procedure.

As many as six consultants reported that the adults found it difficult to describe their learning outcomes in a portfolio: "It was difficult for adults to describe their learning outcomes gained in various learning environments as well as to describe one's major achievements" and that "Adults were unable to present description of knowledge and skills gained non-formally and informally" (Table 1).

Category 4: novelty of the procedure. Response analysis showed that novelty of the procedure caused two difficulties, namely difficulty to understand the procedure of assessment of non-formal and informal learning and portfolio development as well as difficulty to understand the value of the procedure. Three consultants reported that the adults did not fully understand the procedure and how to develop their portfolio: "Adults had a lot of questions about the procedure and the portfolio", "Adults had a lot of questions on the structure of the portfolio" or "They [Adults] didn't understand what reflection was and why it was necessary". Another three consultants noted that the adults were not aware of the value of the procedure: "As this is a new procedure, adults doubted its benefits" and "Adults expressed doubts if the benefits of the procedure would be real" (Table 1). This may be due to the fact that none of the adults had heard about validation of non-formal and informal learning in higher education institutions and about its value to an individual and to his/her future before.

Category 5: personal characteristics. The consultants mentioned that personal characteristics such as lack of self-confidence and lack of determination were a source of difficulty. As many as four consultants stressed that the adults "... doubted if they were capable enough to develop their portfolio" and three consultants highlighted that the adults were not determined to participate in the procedure: "Adults were not sure if they really wanted to participate in the procedure" or "When a difficulty in developing portfolio arose adults started hesitating whether to participate in the procedure" (Table 1). This means that in the future consultants should not only explain to adults what is expected from them in the process of portfolio development, but also to encourage them.

Research conclusions and implications. Content analysis of consultants' responses revealed five important categories of difficulties which adults faced in the process of developing their learning outcomes portfolio at the stage of preparation for assessment of their non-formal and informal learning in higher education institutions, including time constraints, identification and documentation of their learning outcomes, as well as difficulties due to the novelty of the procedure and adults' personal characteristics. 
The study resulted in identification and description of two sub-categories of time constraints that adults faced, including the difficulty to manage and/or plan one's time, lack of time due to big workload and lack of time to compile their learning outcomes portfolio. The fact that at the time of consultations all adults had a job and some of them had more than one job or had a job and were part-time students leads to the conclusion that for some adults time constraints could become the main reason of failure to develop their portfolios. Therefore, institutions implementing validation of non-formal and informal learning should be able to provide guidance and support on a regular basis throughout a prolonged period of time.

The significant finding of the research is that the major challenge for the adults was identification of learning outcomes and their documentation, including the most important task of comparing their learning outcomes against assessment criteria presented in the description of the study programme they intend to claim credit from, which leads to the conclusion that some adults lacked the ability to relate their learning to specified learning outcomes, therefore, targeted guidance to adults is essential at this stage. The research also revealed that selection of relevant evidence was one the most difficult tasks that the adults had to solve. This leads to the conclusion that the mechanism of guidance and support established by the institution should among other formats of support recommend portfolio development courses. This is in line with the findings of Burkšaitienè and Šliogerienè and is similar to the findings of Peters et al. ${ }^{24}$ who reported that the institution-provided portfolio courses can support adults to develop the necessary ability to identify learning outcomes, match them against the learning outcomes required in a particular study programme and document such a match in a portfolio.

The study revealed two difficulties caused by the novelty of the procedure, including the difficulty to understand the rationale behind the assessment procedure and the process of portfolio development (which is a prerequisite of participation in the procedure) and the difficulty to understand the value of the procedure. This leads to the conclusion that institutional support providers should disclose the role and stress the value of the procedure to adults before they start developing their portfolios. This is in line with the evidence presented by Rydel and Peters ${ }^{25}$ on the significance of institutional support to adults.

The results also indicate that the adults demonstrated lack of self-confidence and lack of determination to participate in the procedure of assessment of their non-formal and informal learning outcomes. This leads to the conclusion that encouragement provided by consultants to adults throughout the process of portfolio development is important, whereas determination to participate in the procedure may be boosted by increasing their understanding of the role of the procedure for their future career and its value for personal and professional development.

The study is innovative as it increased understanding of the process of providing guidance and support to adults before the assessment procedure in higher education

24 Burkšaitienė, N.; Šliogerienė, J., supra note 1; Peters, H; Pokorny, H.; Johnson, L., supra note, 6.

25 Rydel, S.T., supra note 6; Peters, H. Contested Discourses: Assessing the Outcomes of Learning from Experience for the Award of Credit in Higher Education. Assessment \& Evaluation in Higher Education. 2005, 30 (3): 273-285. 
institutions in general and of difficulties that the adults encountered in the process of portfolio development as perceived by the consultants who provided guidance and support to them in particular. Future research should focus on the difficulties that the consultants encountered in the process of providing guidance and support to the adults, which might lead to further improvements of institutional support mechanisms.

\section{References}

Baartman, L. K. J. 'Assessing the Assessment': Development and Use of Quality Criteria for Competence Assessment Programmes. Doctoral Dissertation [interactive]. 2008 [accessed on 12-082013]. <http://igitur-archive.library. uu.nl/dissertations/2008-0423-200627/ baartman.pdf $>$.

Bjornavold, J. Validation of Non-formal and Informal Learning in Europe: Key Developments and Challenges. Aukštojo mokslo kokybe / The Quality of Higher Education. 2009, 6: 36-71.

Burkšaitienè, N.; Šliogerienè, J. Neformaliojo ir savaiminio mokymosi pasiekimu vertinimas ir pripažinimas universitete. Vilnius: MRU, 2010.

Burkšaitienè, N.; Teresevičienè, M.; Kaminskienè, L. Portfolio Use for Documentation of Personal and Professional Growth Gained Outside Academia. Baltic Journal of Management. 2011, 6 (2): 245-262.

Costley, C.; Armsby, P. Work-based Learning Assessed as a Field or a Mode of Study. Assessment \& Evaluation in Higher Education. 2007, 32 (1): 21-33.

Council recommendation of 20 December 2012 on the validation of non-formal and informal learning (2012/C 398/01), Official Journal of the European Union. [interactive]. 2012 [accessed on 14-08-2013]. <http://eur-lex.europa. eu/LexUriServ/LexUriServ.do?uri=OJ: C:2012:398:0001:0005:EN:PDF>.

The European Higher Education Area in 2012: Bologna Process Implementation
Report. Brussels: Education, Audiovisual and Culture Executive Agency, 2012.

Finn, J. Validation of Non-formal Adult Education Courses: A New Validation Function for Higher Education Institutions in Europe. In Validation and Recognition of Experiential Learning. Teresevičienè, M., et al. (Eds.). Kaunas: VDU, 2007.

Joosten-ten Brinke, D.; Sluijsmans, D. M. A.; Jochems, W.M.G. Quality of Assessment of Prior Learning (APL) in University Programmes: Perceptions of Candidates, Tutors and Assessors. Studies in Continuing Education. 2009, 31 (1): 61-76.

LR švietimo ir mokslo ministro isakymas (Nr. V-2319) Dèl neformaliojo suaugusiujų švietimo sistemoje igytu kompetenciju vertinimo ir pripažinimo aukštosiose mokyklose rekomendaciju patvirtinimo [interactive]. 2010 [accessed on 08-08-2013]. <http:// tar.tic.lt/Default.aspx?id=2\&item $=$ results \&aktoid=7E500082-A72F47D3-82BF- A0B18D56FBE8>.

A Memorandum on Lifelong Learning. Commission of the European Communities. SEC (2000) 1832. Brussels, 10.30.2000.

Proposal for a Council recommendation on the validation of non-formal and informal learning, 2012, Brussels: European Commission, 5.9.2012, COM (2012) 485 final 2012/0234 (NLE). 
Peters, H. Contested Discourses: Assessing the Outcomes of Learning from Experience for the Award of Credit in Higher Education. Assessment \& Evaluation in Higher Education. 2005, 30 (3): 273-285.

Peters, H.; Pokorny, H.; Johnson, L. Cracking the Code: The Assessment of Prior Experiential Learning at London Metropolitan University. In Portfolio Development and the Assessment of Prior Learning: Perspectives, Models and Practices. Michelson, E., et al. (Eds.). Sterling: Stylus Publishing, 2004, p. 160-179.

Republic of Lithuania. Law on Nonformal Adult Education (No VIII-822) [interactive]. 1998 [accessed on 10-08-
2013]. <http://www3.lrs.lt/pls/inter2/ dokpaieska.showdoc_l?p_id=370996>. Republic of Lithuania. Law on Higher Education and Research (No XI-242), 30 April 2009 [interactive]. 2009 [accessed on 08-08-2013]. <http:// www3.lrs.lt/pls/inter3/dokpaieska. showdoc_l?p_id=366717>.

Rydel, S.T. Building on the Past, Moving Toward the Future: Prior Learning Assessment in a Changing Institution at Metropolitan State University. In Portfolio Development and the Assessment of Prior Learning: Perspectives, Models and Practices. Michelson, E., et al. (Eds.). Sterling: Stylus Publishing, 2004, p. 180-193.

\title{
SUAUGUSIŲJŲ SUNKUMAI RENGIANT MOKYMOSI PASIEKIMŲ APLANKUS: KONSULTANTŲ POŽIŪRIS
}

\author{
Nijolè Burkšaitienè \\ Mykolo Romerio universitetas, Lietuva
}

Santrauka. Pastaruoju metu keletas Lietuvos universitetu ir kolegijų ruošiasi suaugusiuju neformaliojo ir savaiminio mokymosi pasiekimu vertinimo ir pripažinimo procedūros įdiegimui - primami instituciniai teisès aktai, nustatoma procedūra ir jos etapai, apmokomi administracijos darbuotojai ir destytojai bei kuriamos suaugusiesiems skirtos paramos ir pagalbos sistemos. Tyrime dalyvavo 12 konsultantų iš keturiu Lietuvos aukštujų mokyklų, konsultavusių 37 savanorius suaugusiuosius, siekiančius kreditų iš pasirinktǔ šių aukštuju mokyklų studiju programų. Tyrimu siekta nustatyti suaugusiesiems iškilusius sunkumus ruošiant savo mokymosi pasiekimu aplankus vertinimo procedūrai.

Tyrimo rezultatai atskleide, kad suaugusieji susidūrè su penkiu tipu sunkumais: laiko trūkumu, sunkumais nustatant savo mokymosi pasiekimus ir juos dokumentuojant, sunkumais, kuriems turèjo įtakos procedūros naujumas ir suaugusiujų asmeninès savybès.

Išanalizavus konsultantų atsakymus dèl laiko trükumo nustatyta, kad suaugusiesiems buvo sunku planuoti ir suderinti darbo, verslo ir / arba studiju laika su konsultacijų laiku, kad kai kurie iš ju turèjo didelị darbo krūvị ir trūko laiko, kurị būtų galima skirti mokymosi pasiekimu aplankams parengti. 
Tyrimo metu atskleista, kad didžiausias iššūkis suaugusiesiems buvo nustatyti savo mokymosi pasiekimus juos lyginant su pasirinktoje studiju programoje numatytais vertinimo kriterijais (studiju rezultatais / siekiniais ir juos pagristi svariais ir tinkamais irodymais).

Tyrimo duomenys taip pat parodè, kad procedūros naujumas lème tai, kad kai kuriems suaugusiesiems buvo sunku suprasti procedūros ir aplanko rengimo esmę ir ižvelgti procedūros vertę, o nustatyta suaugusiuju pasitikejjimo savimi ir apsisprendimo dalyvauti procedūroje stoka leidžia daryti prielaidą, kad suteikiant paramą (pvz., konsultuojant individualiu ar grupiniu pokalbiu metu) svarbu ne tik suaugusiuosius informuoti, kas turi büti atlikta ruošiantis vertinimo procedūrai, bet ir juos padrąsinti bei kuo išsamiau paaiškinti institucijos teikiamos procedūros svarba individui, jo asmeniniam ir profesiniam augimui bei ateities karjeros galimybèms.

Reikšminiai žodžiai: suaugusiųų sunkumai, mokymosi pasiekimų aplanko rengimas, institucinè parama ir pagalba kandidatams, kreditu siekimas, aukštasis mokslas.

Nijolė Burkšaitienė, Mykolo Romerio universiteto Humanitarinių mokslų instituto Taikomosios filologijos katedros profesorè. Mokslinių tyrimų kryptys: suaugusiųjų mokymasis, specialybės anglų kalbos studijos aukštajame moksle, inovaciniai studijų metodai.

Nijolè Burkšaitienė, Mykolas Romeris University, Institute of Humanities, Department of Applied Languages, Professor. Research interests: adult learning, ESP studies in higher education, innovative teaching and study methods. 